\title{
Modelling the Drying Kinetics of Apple (Golab Variety): Fractional Calculus vs Semi-empirical Models
}

\author{
A. Mahdad, ${ }^{a}$ M. Laidi, ${ }^{\text {, }}$ S. Hanini, ${ }^{a}$ M. Hentabli, ${ }^{\text {and M. Benhelala }}$ \\ a Laboratory of Biomaterials and Transport Phenomena (LBMPT), University of Médéa, \\ Médéa, Algeria \\ b Laboratory Quality Control, Physico-Chemical Department, \\ Antibiotical Saidal of Médéa, Algeria
}

https://doi.org/10.15255/KUI.2020.051

KUI-19/2021

Original scientific paper

Received July 28, 2020

Accepted September 19, 2020

\begin{abstract}
In this work, two novel models have been proposed based on semi-empirical and factional calculus incorporating non-integer time derivatives in the Fick's first law of anomalous diffusion. The experimental data has been collected from literature of 15 kinetics investigated in a convective dryer under the effect of temperatures ranging from 40 to $80{ }^{\circ} \mathrm{C}$ at $10{ }^{\circ} \mathrm{C}$ interval, and thickness of the slices of 2 to $6 \mathrm{~mm}$ at $2 \mathrm{~mm}$ interval. The collected experimental dataset was of apple slices (Golab variety). Results from this study were compared with a set of 64 thin-layer drying models previously published in the literature. The fitting capability of the models was compared using the mean of root mean square error MRMSE (\%) of all kinetics and the global determination coefficient $R^{2}$. All models' constants and coefficients were optimised by dragonfly algorithm programmed in MATLAB software. Results showed that the fractional model is highly capable of describing the drying curve of the apple slices with a determination coefficient $\left(R^{2}\right)$ of 0.99981 , and average root mean square error (MRMSE) of $0.43 \%$ in comparison to the best empirical models with $R^{2}$ of 0.99968 and MRMSE of $0.61 \%$.
\end{abstract}

\section{Keywords}

Thin-layer solar drying, fractional calculus, semi-empirical modelling, apple slices

\section{Introduction}

Drying is an important unit operation the role of which is to reduce the water content of the treated products. ${ }^{1}$ Aimed at neutralizing bacterial activities and fungi, drying allows food products to be preserved for a long time. ${ }^{2}$ It is a technique used worldwide; it allows storing and enhancing agricultural production surpluses in order to market them in times of scarcity. Given the diversity of the products to be dried and industrial processes, each with its specific constraints, the multiplicity of industrial drying techniques has been developed. ${ }^{3-6}$ Several models of thin-layer drying kinetics of agricultural products have been proposed in literature ${ }^{7}$ based on their behaviour, as well as the laws that govern energy and mass conservation, adsorption and desorption rates, heat transfer, and humidity. ${ }^{8,9}$

The goal of our work was to develop two models, fractional and semi-empirical models. The performance of these models has been investigated based on experimental dataset collected from previously published scientific papers of 15 experimental drying kinetics of apples of different layer thickness $(2,4$, and $6 \mathrm{~mm})$, and diverse temperatures $\left(40,50,60,70\right.$, and $\left.80{ }^{\circ} \mathrm{C}\right)$. The accuracy of these models has been compared with 64 models from literature for thin-layer drying kinetics.

*Corresponding author: Dr Maamar Laidi

Email: maamarw@yahoo.fr

\section{Modelling of the phenomenon of solar drying}

Several mathematical models are proposed in the literature to model the drying kinetics of different products, in particular the semi-empirical models, which come from the drying phenomenology. ${ }^{10}$ Table 1 presents 64 models published in the literature and tested on the drying of agrifood products. The moisture content evolution in agricultural products is directly proportional to its own moisture content $^{11}$ (see Eq. 1).

$$
\frac{d^{\alpha} X(t)}{d^{\alpha} t}=D_{t}^{\alpha} X(t)=-k_{n}\left(X(t)-X_{\mathrm{e}}\right)^{n}
$$

where $X(0)=X_{0}, k$ is the kinetic constant of the model, $X_{0}$ the initial moisture content, $X_{\mathrm{e}}$ is the equilibrium moisture content, and $\alpha$ is the fractional time index where $0<\alpha<1$ with $\alpha \in R .^{12}$ The moisture ratio can be expressed and simplified into the following formula and after considering that $X_{\mathrm{e}}$ is too small compared to $X(t)$ and $X_{0}$.

$$
M R(t)=\frac{X(t)-X_{\mathrm{e}}}{X_{0}-X_{\mathrm{e}}} \approx \frac{X_{\mathrm{t}}}{X_{0}}
$$

$X(t)$ is the moisture content at time $t$, which is given by $X(t)=\frac{m_{\mathrm{h}}-m_{\mathrm{s}}}{m_{\mathrm{s}}}, m_{\mathrm{h}}$ is the successive weightings change of the wet product until it becomes stationary, $m_{\mathrm{s}}$ is the dry mass of the product and was determined by drying the samples at $105{ }^{\circ} \mathrm{C}$ until the weight became constant. ${ }^{13,14}$ 
Eq. 1 can be expressed in terms of moisture by Eq. 3:

$$
\frac{\partial^{\alpha} M R(t)}{\partial^{\alpha} t}=-K_{\alpha} M R(t)^{n}
$$

with $K_{\alpha}=\frac{k_{\alpha} X_{0}^{\alpha}}{X_{0}^{n}}$, the solution of Eq. (3) gives the fractional model. See Eq. (4):

$$
M R(t)=\left[\frac{1}{\frac{(n-1) K_{\alpha} t^{\alpha}}{(\alpha+1)}+\frac{1}{C_{0}{ }^{n-1}}}\right]^{\frac{1}{n-1}}
$$

with $\alpha$ as the whole order between $1<\alpha<2, K_{\alpha}$ as the fractional rate constant, and $n$ as the order of the reaction. These models were tested on 15 solar drying kinetics taken from the literature, of apple in a thin layer under the effect of 3 different thicknesses $\{2,4$, and $6 \mathrm{~mm}\}$, and 5 different temperatures $\left\{40,50,60,70\right.$, and $\left.80{ }^{\circ} \mathrm{C}\right\} .{ }^{15}$ The second developed model in this work is a semi-empirical model.

\begin{tabular}{|c|c|c|c|}
\hline Model Name & Equations & Code & Ref. \\
\hline Lewis & $M R=\exp (-k t)$ & MR1 & 7 \\
\hline Page & $M R=\exp \left(-k t^{n}\right)$ & MR2 & 7 \\
\hline Modifie Page I & $M R=\exp \left[\left(-k t^{n}\right)\right]$ & MR3 & 7 \\
\hline Modifie Page II & $M R=\exp \left[-\left(k t^{n}\right)\right]$ & MR4 & 7 \\
\hline Modifie Page III & $M R=\exp \left[-\left(-k t^{n}\right)\right]$ & MR5 & 7 \\
\hline Modifie Page IV & $M R=\operatorname{aexp}\left[-\left(k t^{n}\right)\right]$ & MR6 & 7 \\
\hline Modifie Page V & $M R=\exp \left[-\left(k t^{n}\right)\right]$ & MR7 & 7 \\
\hline Modifie Page VI & $M R=\exp \left(k t^{n}\right)$ & MR8 & 7 \\
\hline Modifie Page VII & $M R=\exp \left[-k\left(\frac{t}{L^{2}}\right)^{n}\right]$ & MR9 & 7 \\
\hline Modifie Page IX & $M R=\operatorname{kexp}\left[\left(\frac{-t}{L^{2}}\right)^{n}\right]$ & MR10 & 7 \\
\hline Otsura et al. & $M R=1-\exp \left[-\left(k t^{n}\right)\right]$ & MR11 & 7 \\
\hline Fick Simplifie & $M R=k \exp \left[-C\left(\frac{t}{L^{2}}\right)\right]$ & MR12 & 7 \\
\hline Henderson and Pabis & $M R=a \exp (-k t)$ & MR13 & 7 \\
\hline Modifie Henderson and Pabis - I & $M R=a \exp \left(-k_{0} t\right)+b \exp \left(-k_{1} t\right)+c \exp \left(-k_{2} t\right)$ & MR14 & 7 \\
\hline Modifie Henderson and Pabis - II & $M R=\operatorname{aexp}\left(-k t^{n}\right)+b \exp (-g t)+c \exp (-h t)$ & MR15 & 7 \\
\hline Logaritmic & $M R=a \exp (-k t)+c$ & MR16 & 7 \\
\hline TwoTerm & $M R=a \exp \left(-k_{0} t\right)+b \exp \left(-k_{1} t\right)$ & MR17 & 7 \\
\hline Modifie TwoTerm - I & $M R=a \exp \left(k_{0} t\right)+(1-a) \exp \left(-k_{1} t\right)$ & MR18 & 7 \\
\hline Modifie TwoTerm - II & $M R=a \exp \left(k_{0} t\right)+(1-a) \exp \left(k_{1} t\right)$ & MR19 & 7 \\
\hline Modifie TwoTerm - III & $M R=a \exp \left(-k_{0} t\right)+a \exp \left(-k_{1} t\right)$ & MR20 & 7 \\
\hline
\end{tabular}

Table 1 - Thin-layer drying models tested in this work 
Table 1 - (continued)

\begin{tabular}{|c|c|c|c|}
\hline Model Name & Equations & Code & Ref. \\
\hline Modifie TwoTerm - IV & $M R=a \exp \left(-k_{0} t^{n}\right)+b \exp \left(-k_{1} t\right)$ & MR21 & 7 \\
\hline Modifie TwoTerm - V & $M R=a \exp \left(-k_{0} t\right)+(1-a) \exp \left(-k_{1} t\right)$ & MR22 & 7 \\
\hline TwoTermExponential & $M R=a \exp (-k t)+(1-a) \exp (-k a t)$ & MR23 & 7 \\
\hline Verma et al. & $M R=a \exp (-k t)+(1-a) \exp (-g t)$ & MR24 & 7 \\
\hline Diffusion Approximation & $M R=a \exp (-k t)+(1-a) \exp (-k b t)$ & MR25 & 7 \\
\hline Midilli et al. & $M R=a \exp \left(-k t^{n}\right)+b t$ & MR26 & 7 \\
\hline Modifie Midilli - I & $M R=\exp \left(-k t^{n}\right)+b t$ & MR27 & 7 \\
\hline Modifie Midilli - II & $M R=\exp (-k t)+b t$ & MR28 & 7 \\
\hline Modifie Midilli - III & $M R=a \exp (-k t)+b t$ & MR29 & 7 \\
\hline Wang and Singh & $M R=1+a t+b t^{2}$ & MR30 & 7 \\
\hline Hii et al. & $M R=a \exp \left(-k t^{n}\right)+c \exp \left(-g t^{n}\right)$ & MR31 & 7 \\
\hline Weibull Distribution - I & $M R=a-b \exp \left[-\left(k t^{n}\right)\right]$ & MR32 & 7 \\
\hline Weibull Distribution - II & $M R=a-b \exp \left[-k t^{n}\right]$ & MR33 & 7 \\
\hline Weibull Distribution - III & $M R=\exp \left[-(t / a)^{n}\right]$ & MR34 & 7 \\
\hline Vega-Galvez et al. - I & $M R=n+k \sqrt{t}^{n}$ & MR35 & 7 \\
\hline Vega-Galvez et al. - II & $M R=\exp (n+k t)$ & MR36 & 7 \\
\hline Vega-Galvez et al. - III & $M R=(a+b t)^{2}$ & MR37 & 7 \\
\hline Jena Das & $M R=a \exp (-k t+b \sqrt{t})+c$ & MR38 & 7 \\
\hline Wang et al. One Term & $M R=a \exp (b k t)+(1-a)$ & MR39 & 7 \\
\hline Wang et al. Two Term & $M R=(1-a) \exp (b k t)+a \exp (c k t)$ & MR40 & 7 \\
\hline Wang et al. Three Term & $M R=(1-a-b) \exp (c k t)+a \exp (d k t)+b \exp (f k t)$ & MR41 & 7 \\
\hline Demir et al. & $M R=\operatorname{aexp}\left[(-k t)^{n}\right]+b$ & MR42 & 7 \\
\hline Haghi and Angiz - I & $M R=a \exp \left(-b t^{c}\right)+d t^{2}+e t+f$ & MR43 & 7 \\
\hline Haghi and Angiz - II & $M R=a+b t+c t^{2}+d t^{3}$ & MR44 & 7 \\
\hline Haghi and Angiz - III & $M R=\frac{a+b t}{1+c t+c t^{2}}$ & MR45 & 7 \\
\hline Haghi and Angiz - IV & $M R=\operatorname{aexp}\left[\frac{-(t-b)^{2}}{2 c^{2}}\right]$ & MR46 & 7 \\
\hline Sripinyowanich and Noomhorm & $M R=\exp \left(-k t^{n}\right)+b t+c$ & MR47 & 7 \\
\hline Noomhorm and Verma & $M R=a \exp (-k t)+b \exp (-g t)+c$ & MR48 & 7 \\
\hline Hasibuan and Daud & $M R=1-a t^{n} \exp \left(-k t^{m}\right)$ & MR49 & 7 \\
\hline SharefEldeen et al. & $M R=a \exp (k t)+[1-a \exp (-b k t)]$ & MR50 & 7 \\
\hline
\end{tabular}


Table $1-$ (continued)

\begin{tabular}{|c|c|c|c|}
\hline Model Name & Equations & Code & Ref. \\
\hline Henderson and Henderson I & $M R=c\left[\exp (-k t)+\frac{1}{9} \exp (-9 k t)\right]$ & MR51 & 7 \\
\hline Henderson and Henderson II & $M R=c \exp (-k t)+\frac{1}{9} \exp (-9 k t)$ & MR52 & 7 \\
\hline Parabolic & $M R=a+b t+c t^{2}$ & MR53 & 7 \\
\hline Geometric & $M R=a t^{-n}$ & MR54 & 7 \\
\hline Logistic & $M R=\frac{a_{0}}{[1+a \exp (k t)]}$ & MR55 & 7 \\
\hline Power Law & $M R=a t^{b}$ & MR56 & 7 \\
\hline Regression - I & $M R=\exp \left[-\left(a t^{2}+b t\right)\right]$ & MR57 & 7 \\
\hline Chavez-Mendez et al. & $M R=a+b \ln (t)$ & MR58 & 7 \\
\hline Aghbashlo & $M R=\exp \left[-\frac{k_{1} t}{\left(1+k_{2} t\right)}\right]$ & MR59 & 7 \\
\hline Modifie Henderson and Perry & $M R=a \exp \left(-k t^{n}\right)$ & MR60 & 7 \\
\hline Three Parameter & $M R=a \exp \left[-(k t)^{n}\right]$ & MR61 & 7 \\
\hline Asymptotic & $M R=a_{0}+a \exp (-k t)$ & MR62 & 7 \\
\hline Khazaei and Daneshmandi & $M R=a+\exp (-b t)-c t$ & MR63 & 7 \\
\hline Proposed model I & $M R=\exp \left[-\left(a t^{n}+b t\right)\right]$ & MR64 & This study \\
\hline Kaleemullah 2006 & $M R=\exp \left(-(a t+b) t^{(c t+d)}\right.$ & MR65 & 16 \\
\hline Proposed model II & $M R=\left[\frac{1}{\frac{(n-1) K_{\alpha} t^{\alpha}}{(\alpha+1)}+\frac{1}{C_{0}^{n-1}}}\right]^{\frac{1}{n-1}}$ & MR66 & This study \\
\hline
\end{tabular}

\section{Results and discussion}

\subsection{Results of semi-empirical modelling}

Parameter adjustments of selected models from literature (64 models), as well as the proposed model were performed using dragonfly and swarm algorithms (DA MATLAB function). To avoid convergence to local minima, optimisation using dragonfly and swarm algorithms was performed 20 times. The optimised parameters of each model were used to estimate the moisture ratio and compare it with the experimental moisture ratio. The performance of each model was measured using different statistical parameters, like root mean square error (RMSE), reduced chi-squared $\left(X^{2}\right)$, modelling efficiency $(E F)$, and determination coefficient $\left(R^{2}\right)$ for each kinetic and for each model. The average of these parameters for about 276 experimental points covering the
15 kinetics are presented in Table 2. The best performing model was selected based on the smallest average error $(\approx 0)$ and the largest coefficient of determination $(\approx 1)$. The mathematical formulas of these errors are presented in the articles cited in these references. ${ }^{17-23}$

In order to simplify the comparison, the performances of the best 16 models are shown in Table 3 and Fig. 1, after having classified them from the smallest value to the largest value of MRMSE. The comparison between the performances of the different models indicates that the model proposed in this work MR64 provides the best correlation performance, where the value of MRMSE is $(\approx 0.43 \%)$. The second best correlation performance is given by the coded model MR57, where the MRMSE has a value of $(\approx 0.61 \%)$. 
Table 2 - Results of calculation of the means of the statistical parameters

\begin{tabular}{|c|c|c|c|c|}
\hline Model code & MRMSE & $M X^{2}$ & $\mathrm{MR}^{2}$ & MEF \\
\hline MR1 & 0.02470 & 0.00439 & 0.995315 & 0.99192 \\
\hline MR2 & 0.00632 & 0.00038 & 0.993841 & 0.99949 \\
\hline MR3 & 0.70613 & 0.03676 & 0.989492 & -3.94113 \\
\hline MR4 & 0.00632 & 0.03050 & 0.999572 & 0.99949 \\
\hline MR5 & 0.23524 & 0.00614 & 0.924816 & -0.10991 \\
\hline MR6 & 0.03687 & 0.00392 & 0.98012 & 0.96187 \\
\hline MR7 & 0.00632 & 0.00138 & 0.999661 & 0.99949 \\
\hline MR8 & 0.00632 & 0.00140 & 0.988855 & 0.99949 \\
\hline MR9 & 0.37653 & 0.02497 & 0.24018 & -0.53374 \\
\hline MR10 & 0.42449 & 0.15176 & 0.240178 & -0.78284 \\
\hline MR11 & 0.05268 & 0.00178 & 0.987291 & 0.97250 \\
\hline MR12 & 0.34640 & 0.15171 & 0.377639 & -0.27247 \\
\hline MR13 & 0.02058 & 0.00006 & 0.996043 & 0.99460 \\
\hline MR14 & 0.02001 & 0.00268 & 0.990786 & 0.99313 \\
\hline MR15 & 0.04604 & 0.00006 & 0.952705 & 0.95388 \\
\hline MR16 & 0.03987 & 0.00167 & 0.935228 & 0.94958 \\
\hline MR17 & 0.01830 & 0.00267 & 0.947923 & 0.99249 \\
\hline MR18 & 0.00809 & 0.01290 & 0.999281 & 0.99914 \\
\hline MR19 & 0.00678 & 0.00400 & 0.998558 & 0.99933 \\
\hline MR20 & 0.04672 & 0.00030 & 0.97757 & 0.96264 \\
\hline MR21 & 0.02446 & 0.00573 & 0.956404 & 0.98815 \\
\hline MR22 & 0.00809 & 0.00772 & 0.999225 & 0.99918 \\
\hline MR23 & 0.02016 & 0.00439 & 0.997007 & 0.99488 \\
\hline MR24 & 0.00824 & 0.00038 & 0.999091 & 0.99912 \\
\hline MR25 & 0.00681 & 0.03676 & 0.999158 & 0.99925 \\
\hline MR26 & 0.18126 & 0.03050 & 0.536473 & 0.51637 \\
\hline MR27 & 0.10073 & 0.00614 & 0.737014 & 0.79737 \\
\hline MR28 & 0.01949 & 0.00392 & 0.930226 & 0.99312 \\
\hline MR29 & 0.14617 & 0.00138 & 0.780538 & 0.58332 \\
\hline MR30 & 0.03535 & 0.00140 & 0.890798 & 0.97863 \\
\hline MR31 & 0.07696 & 0.02497 & 0.830475 & 0.89322 \\
\hline MR32 & 0.07730 & 0.15176 & 0.912332 & 0.91464 \\
\hline MR33 & 0.09243 & 0.00178 & 0.898699 & 0.85327 \\
\hline
\end{tabular}

\begin{tabular}{|c|c|c|c|c|}
\hline Model code & MRMSE & $M X^{2}$ & $\mathrm{MR}^{2}$ & MEF \\
\hline MR34 & 0.00632 & 0.15171 & 0.996306 & 0.99949 \\
\hline MR35 & 0.05906 & 0.00006 & 0.983223 & 0.96395 \\
\hline MR36 & 0.02058 & 0.00268 & 0.99675 & 0.99460 \\
\hline MR37 & 0.02667 & 0.00006 & 0.994811 & 0.99221 \\
\hline MR38 & 0.11913 & 0.00167 & 0.888276 & 0.76815 \\
\hline MR39 & 0.03493 & 0.00267 & 0.965836 & 0.95844 \\
\hline MR40 & 0.01623 & 0.01290 & 0.997865 & 0.99598 \\
\hline MR41 & 0.00957 & 0.00400 & 0.991579 & 0.99876 \\
\hline MR42 & 0.27060 & 0.00030 & 0.68628 & 0.17489 \\
\hline MR43 & 0.41069 & 0.00573 & 0.467703 & -3.97645 \\
\hline MR44 & 1.33998 & 0.00772 & 0.771128 & -43.16799 \\
\hline MR45 & 0.05469 & 0.00439 & 0.96633 & 0.96772 \\
\hline MR46 & 0.01647 & 0.00038 & 0.992901 & 0.99692 \\
\hline MR47 & 0.14314 & 0.03676 & 0.828988 & 0.72248 \\
\hline MR48 & 0.10609 & 0.03050 & 0.937033 & 0.78844 \\
\hline MR49 & 0.04610 & 0.00614 & 0.848811 & 0.95346 \\
\hline MR50 & 0.03360 & 0.00392 & 0.956268 & 0.97026 \\
\hline MR51 & 0.03334 & 0.00138 & 0.993357 & 0.98753 \\
\hline MR52 & 0.03373 & 0.00140 & 0.993219 & 0.98737 \\
\hline MR53 & 0.08623 & 0.02497 & 0.736838 & 0.80391 \\
\hline MR54 & 0.36640 & 0.15176 & 0.394482 & -0.31502 \\
\hline MR55 & 0.03102 & 0.00178 & 0.994644 & 0.98602 \\
\hline MR56 & 0.36634 & 0.15171 & 0.434155 & -0.31463 \\
\hline MR57 & 0.00609 & 0.00062 & 0.999681 & 0.99949 \\
\hline MR58 & 0.04635 & 0.00268 & 0.985938 & 0.97258 \\
\hline MR59 & 0.00701 & 0.00006 & 0.999353 & 0.99930 \\
\hline MR60 & 0.01387 & 0.00167 & 0.95625 & 0.98627 \\
\hline MR61 & 0.03375 & 0.00267 & 0.983897 & 0.97329 \\
\hline MR62 & 0.05857 & 0.01290 & 0.952211 & 0.87420 \\
\hline MR63 & 0.04689 & 0.00400 & 0.971614 & 0.96073 \\
\hline MR64 & 0.00429 & 0.00030 & 0.999814 & 0.99967 \\
\hline MR65 & 0.04619 & 0.00573 & 0.919098 & 0.95821 \\
\hline
\end{tabular}

Table 3 - Comparative table of the 16 models considered

\begin{tabular}{c|c|c|c|c}
\hline Model index & MRMSE $/ \%$ & $M X^{2}$ & $M^{2}$ & $M E F$ \\
\hline MR64 & $\mathbf{0 . 4 3}$ & $\mathbf{0 . 0 0 0 3 0}$ & $\mathbf{0 . 9 9 9 8 1 4}$ & $\mathbf{0 . 9 9 9 6 7}$ \\
\hline MR57 & $\mathbf{0 . 6 1}$ & $\mathbf{0 . 0 0 0 0 6}$ & $\mathbf{0 . 9 9 9 6 8 1}$ & $\mathbf{0 . 9 9 9 4 9}$ \\
\hline MR7 & 0.63 & 0.00138 & 0.999661 & 0.99949 \\
\hline MR4 & 0.63 & 0.03050 & 0.999572 & 0.99949 \\
\hline MR8 & 0.63 & 0.00140 & 0.988855 & 0.99949 \\
\hline MR2 & 0.63 & 0.00038 & 0.993841 & 0.99949 \\
\hline MR34 & 0.63 & 0.15171 & 0.996306 & 0.99949 \\
\hline MR19 & 0.68 & 0.00400 & 0.998558 & 0.99933 \\
\hline
\end{tabular}

\begin{tabular}{c|c|c|c|c}
\hline Model index & MRMSE $/ \%$ & $M^{2}$ & $M^{2}$ & MEF \\
\hline MR25 & 0.68 & 0.03676 & 0.999158 & 0.99925 \\
\hline MR59 & 0.70 & 0.00006 & 0.999353 & 0.9993 \\
\hline MR22 & 0.81 & 0.00772 & 0.999225 & 0.99918 \\
\hline MR18 & 0.81 & 0.01290 & 0.999281 & 0.99914 \\
\hline MR24 & 0.82 & 0.00038 & 0.999091 & 0.99912 \\
\hline MR41 & 0.96 & 0.00400 & 0.991579 & 0.99876 \\
\hline MR60 & 1.39 & 0.00167 & 0.95625 & 0.98627 \\
\hline MR40 & 1.62 & 0.01290 & 0.997865 & 0.99598 \\
\hline
\end{tabular}




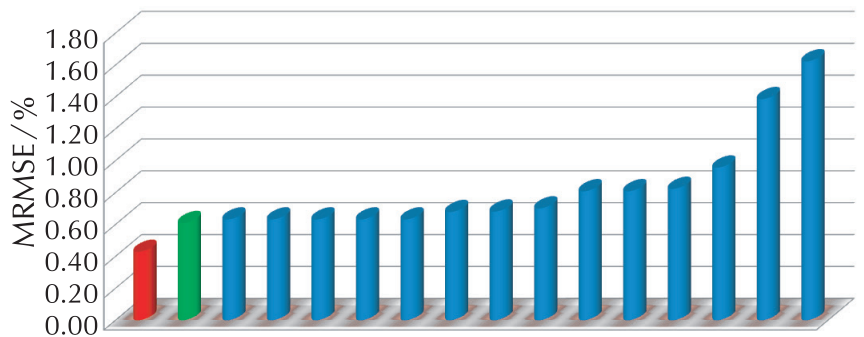

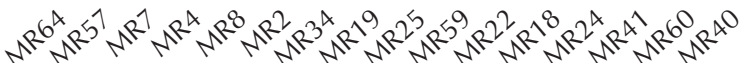

Fig. 1 - Classification of the 16 models considered for solar drying of the apple thin layer

\subsection{Comparison of the performance of the two selected models}

The comparison between the two selected models (MR64 and MR57) is presented in the form of kinetics curves in which the moisture content (MR) is plotted against time. Figs. 2-4 represent the modelling results by the two models of the fifteen drying kinetics of a thin layer of apple at different thicknesses and drying temperatures. Results
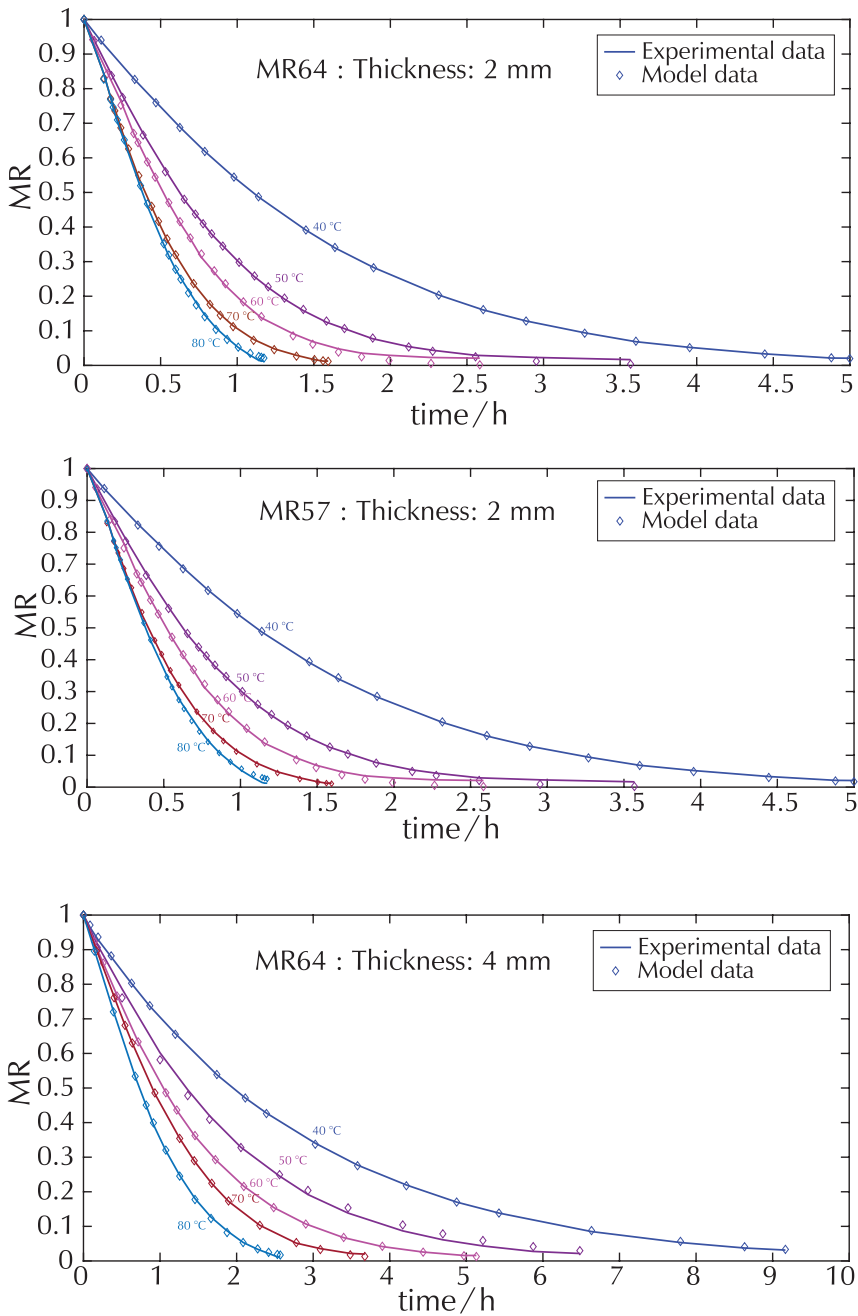

show a slight superiority of the MR64 model compared to the MR57 model when modelling the experimental data of apple drying. Another comparison was made in terms of linear regression between the predicted and experimental rate of humidity (MR) to assess the ability of both models MR64 and MR57 to model solar drying kinetics. Figs 5-7 show the juxtaposition of the first bisector and the line of the best linear fit of the output with the target, as well as the distribution of the experimental points confirming the excellent agreement between the moisture rate calculated by the two models and that of the experiment under different thicknesses and different temperatures for the entire database. Table 4 summarizes the errors and the linear regression vectors that are very close to ideal for all kinetics.

Table 4 - Errors and linear regression vectors obtained for the two models

\begin{tabular}{c|c|c|c|c}
\hline Model & A & $\beta$ & $R$ & MRMSE \\
\hline MR64 & 1 & $-4.3 \cdot 10^{-05}$ & 0.99981 & 0.00429 \\
\hline MR57 & 1 & 0.0014 & 0.99974 & 0.00609 \\
\hline
\end{tabular}
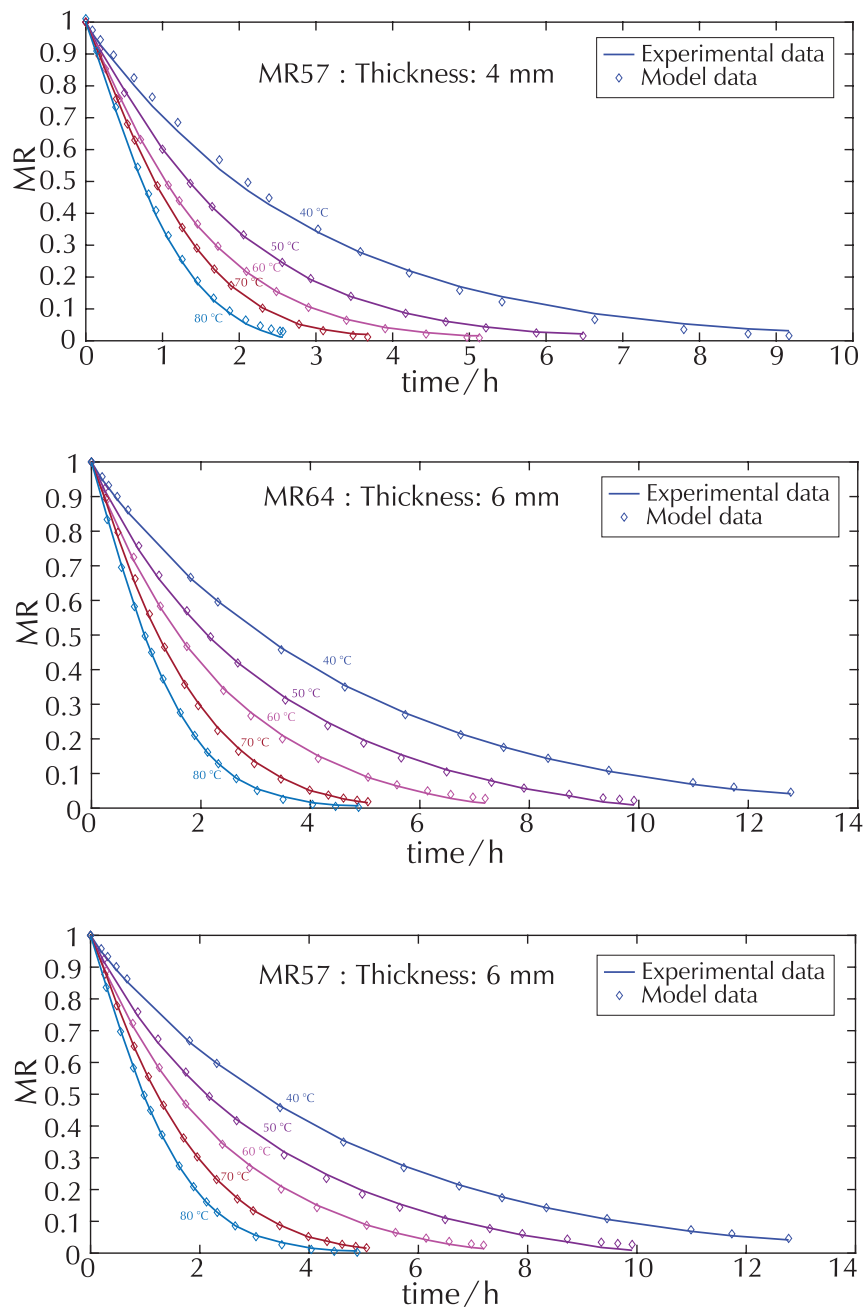

Fig. 2 - Performance of each MR57 and MR64 model to predict drying kinetics 

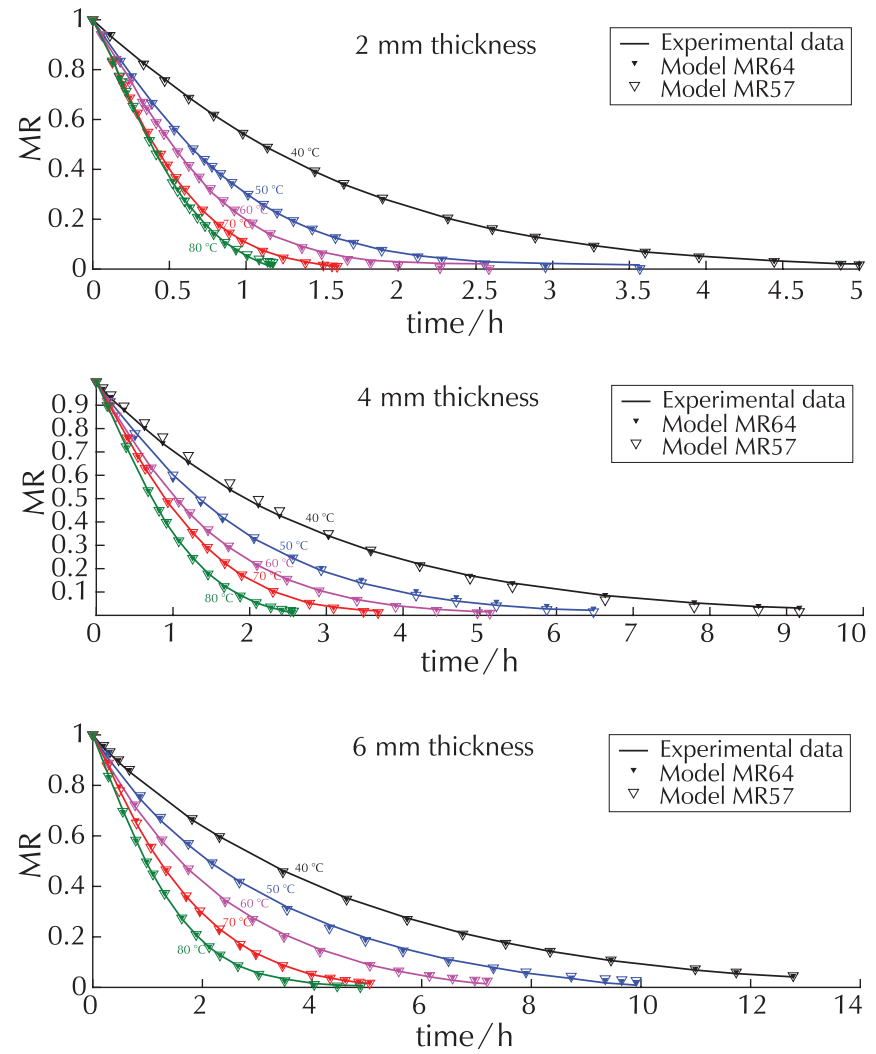

Fig. 3 - Comparison between the two models to predict the drying kinetics vs temperature at different thicknesses
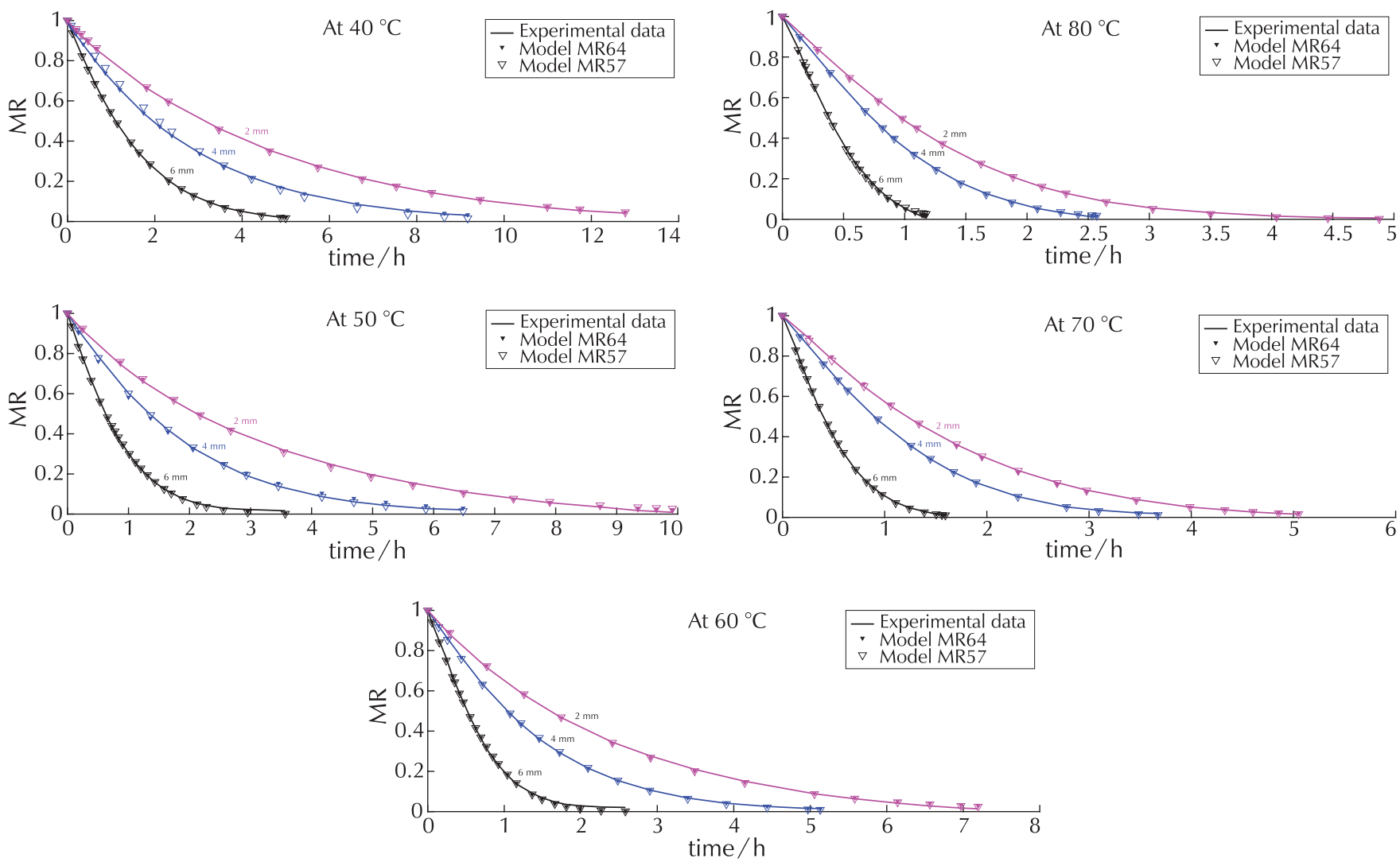

Fig. 4 - Comparison between the two models to predict the drying kinetics vs thicknesses at different temperatures 
MR64 Best Linear Fit

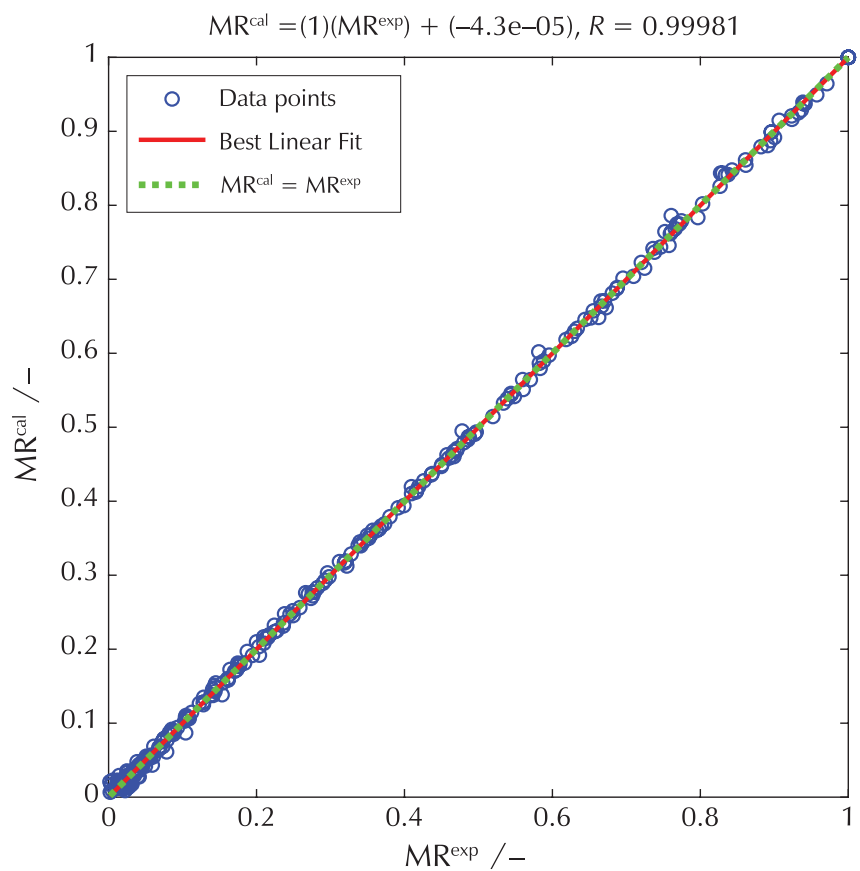

MR57 Best Linear Fit

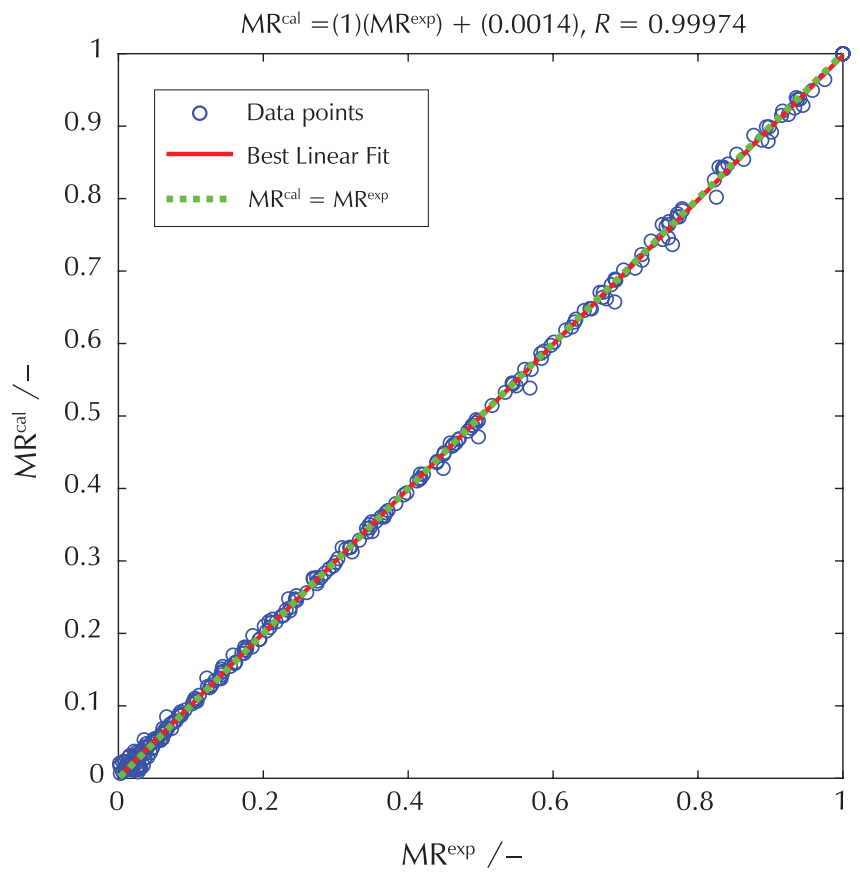

Fig. 5 - Linear regression between the experimental and the calculated moisture ratio using the proposed model (MR64) and the regression I model (MR57)

\subsection{Fractional modelling results}

This methodology was applied to fifteen drying kinetics of apple pieces in a thin layer under the effect of different temperatures and thicknesses. The results of the fractional modelling were then compared to those of the two best performing models found. The comparison was made using the mean statistical parameters and in the form of graphical illustrations and tables. The parameters of the fractional model were optimised using the "dragonfly" optimisation method programmed in the MATLAB software. Optimisation results are presented in Table 5 . In order to avoid local minima caused by the optimisation method, each optimisation operation was repeated 20 times.

Table 5 - Statistical parameters optimised by fractional model

\begin{tabular}{|c|c|c|c|c|c|c|c|}
\hline \multirow{2}{*}{$T / C^{\circ}$} & \multirow{2}{*}{ Thickness/mm } & \multicolumn{3}{|c|}{ Statistical parameters } & \multicolumn{3}{|c|}{ Coefficients } \\
\hline & & RMSE & $x^{2}$ & $R^{2}$ & $k$ & $\alpha$ & $n$ \\
\hline \multirow{3}{*}{40} & 2 & 0.00238 & 0.00001 & 1.0000 & 0.641 & 1.091 & 0.954 \\
\hline & 4 & 0.00421 & 0.00002 & 0.9999 & 1.260 & 1.139 & 0.972 \\
\hline & 6 & 0.02233 & 0.00057 & 0.9996 & 1.000 & 0.887 & 0.497 \\
\hline \multirow{3}{*}{50} & 2 & 0.01428 & 0.00024 & 0.9998 & 1.000 & 0.769 & 0.286 \\
\hline & 4 & 0.00651 & 0.00005 & 0.9988 & 1.000 & 0.772 & 0.127 \\
\hline & 6 & 0.00192 & 0.00000 & 1.0000 & 0.346 & 0.979 & 0.918 \\
\hline \multirow{3}{*}{60} & 2 & 0.00241 & 0.00001 & 1.0000 & 0.513 & 1.058 & 0.941 \\
\hline & 4 & 0.00559 & 0.00004 & 1.0000 & 0.755 & 1.181 & 1.086 \\
\hline & 6 & 0.00958 & 0.00011 & 0.9999 & 1.000 & 1.302 & 1.119 \\
\hline \multirow{3}{*}{70} & 2 & 0.00413 & 0.00002 & 0.9998 & 0.896 & 1.068 & 0.672 \\
\hline & 4 & 0.00120 & 0.00000 & 1.0000 & 0.220 & 0.937 & 0.828 \\
\hline & 6 & 0.00461 & 0.00003 & 0.9999 & 0.306 & 0.865 & 0.695 \\
\hline \multirow{3}{*}{80} & 2 & 0.00285 & 0.00001 & 1.0000 & 0.399 & 0.923 & 0.752 \\
\hline & 4 & 0.00170 & 0.00000 & 0.9998 & 0.553 & 1.087 & 0.854 \\
\hline & 6 & 0.00419 & 0.00002 & 0.9998 & 0.804 & 1.216 & 0.987 \\
\hline \multicolumn{2}{|c|}{ Average } & $0.59 \%$ & 0.00008 & 0.99981 & - & - & - \\
\hline
\end{tabular}


MR64 (Ep $=2 \mathrm{~mm})$

Best Linear Fit : $M R^{\exp }=(1)\left(M^{\text {cal }}\right)+(0.0013), R=0.99985$

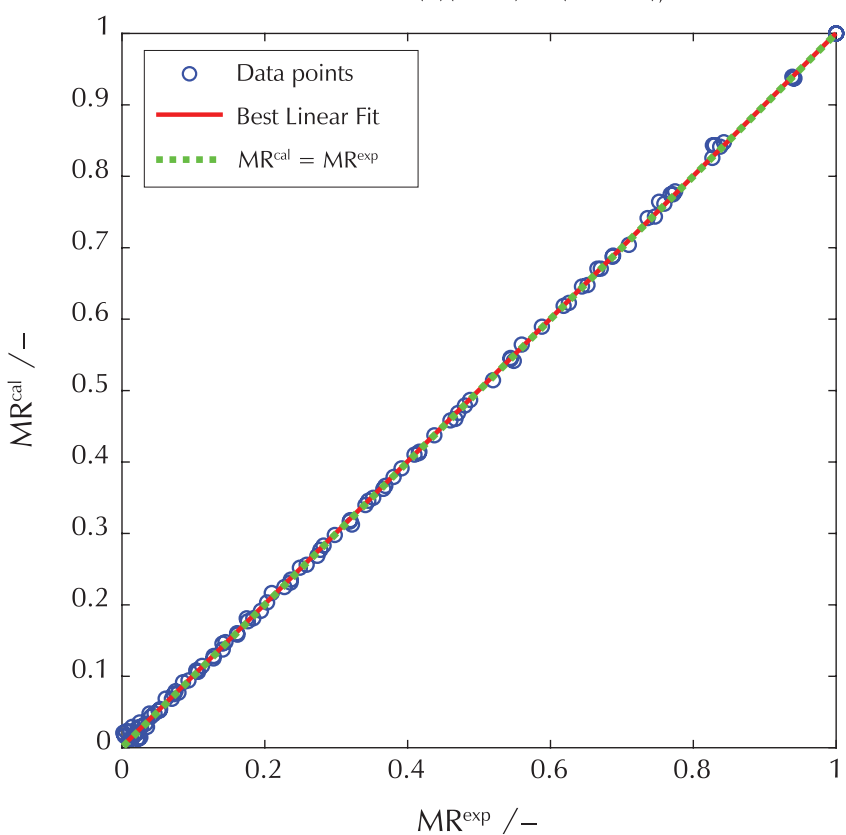

MR64 (Ep $=4 \mathrm{~mm})$

Best Linear Fit : $M R^{\exp }=(1)\left(M^{\text {cal }}\right)+(-0.0023), R=0.99982$

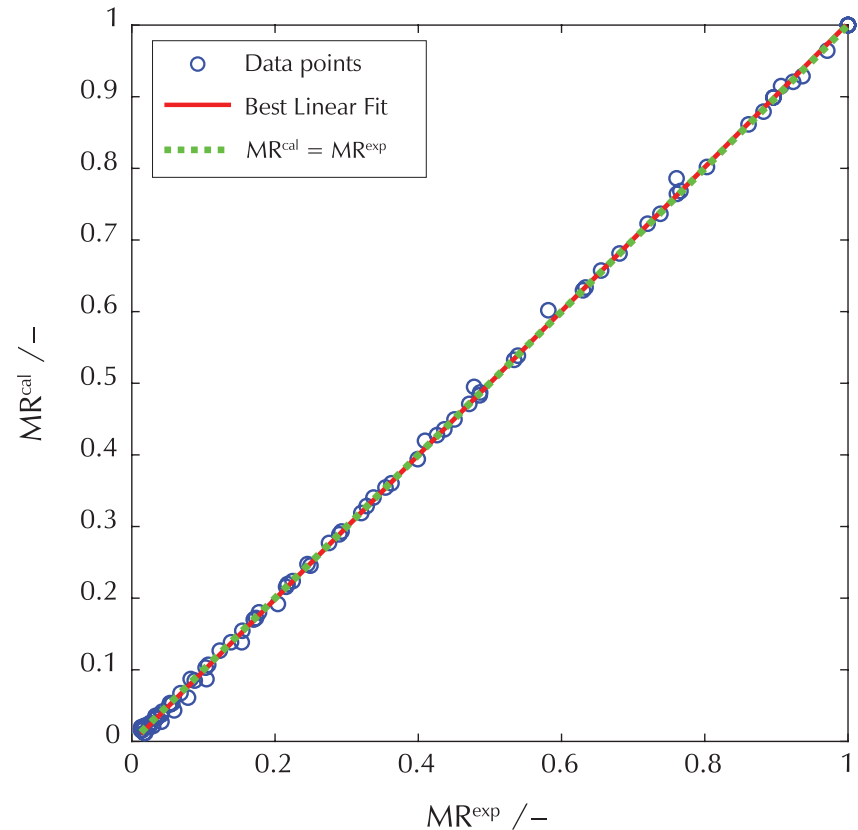

MR64 $(\mathrm{Ep}=6 \mathrm{~mm})$

Best Linear Fit : $M R^{\exp }=(1)\left(M^{\text {cal }}\right)+(0.00038), R=0.9998$

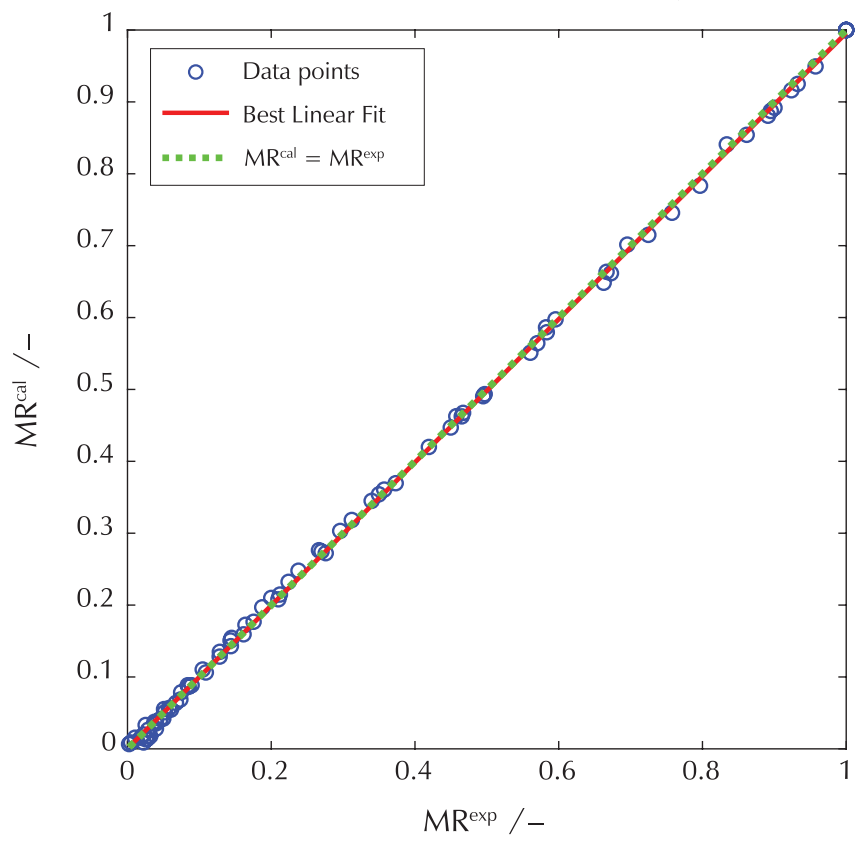

Fig. 6 - Linear regression between the experimental and the calculated moisture ratio using the proposed model (MR64) at different thicknesses (Ep) of the 15 selected kinetics

A comparison in terms of histograms between the three best models was made by the overall coefficient of determination and the average of the mean absolute relative errors of the 15 drying kinetics of the apple in a thin layer (see Table 6).
Table 6 - Comparison between the three models

\begin{tabular}{c|c|c|c|c}
\hline Model & MRMSE $/ \%$ & $\mathrm{XM}^{2}$ & $R^{2}$ & EFM \\
\hline Fractional & 0.59 & 0.00008 & 0.99981 & 0.99934 \\
\hline MR57 & 0.61 & 0.00062 & 0.99968 & 0.99949 \\
\hline MR64 & 0.43 & 0.00030 & 0.99981 & 0.99967 \\
\hline
\end{tabular}


MR57 (Ep $=2 \mathrm{~mm})$

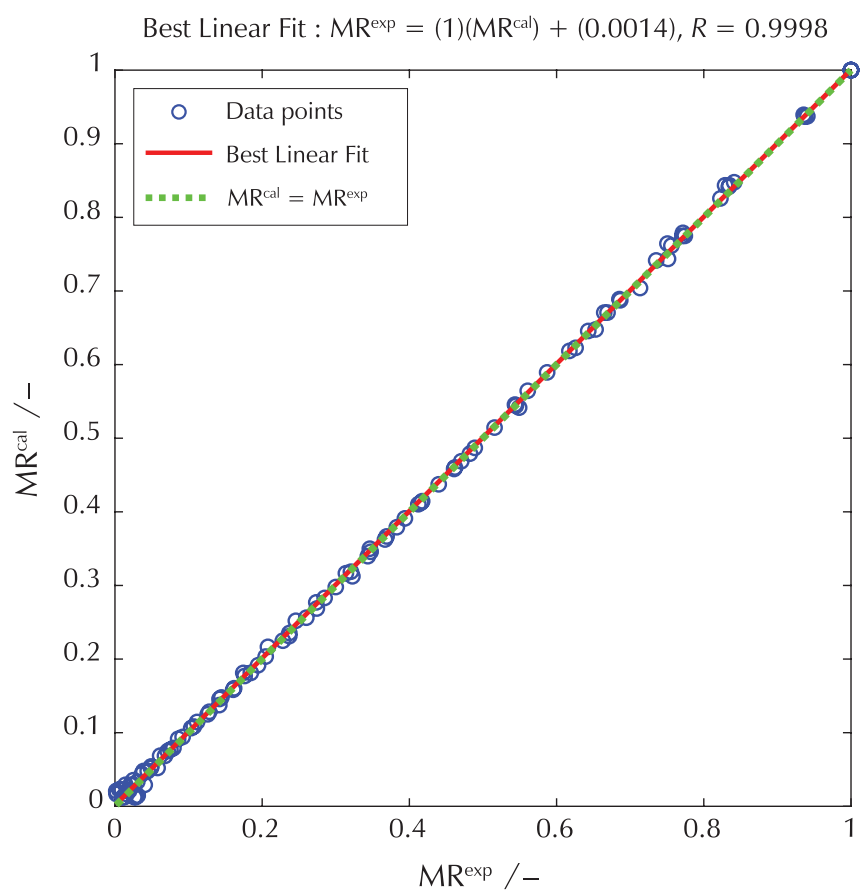

$\operatorname{MR57}(\operatorname{Ep}=4 \mathrm{~mm})$

Best Linear Fit : $M R^{\exp }=(0.99)\left(M^{\text {cal }}\right)+(0.0031), R=0.99964$

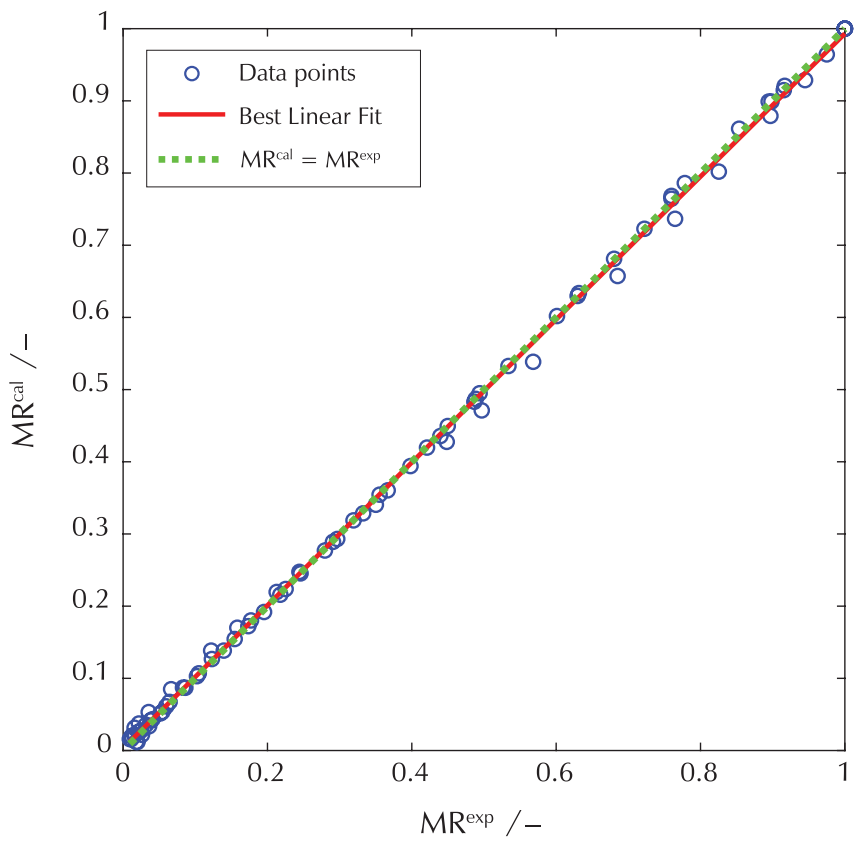

$\operatorname{MR57}(\mathrm{Ep}=6 \mathrm{~mm})$

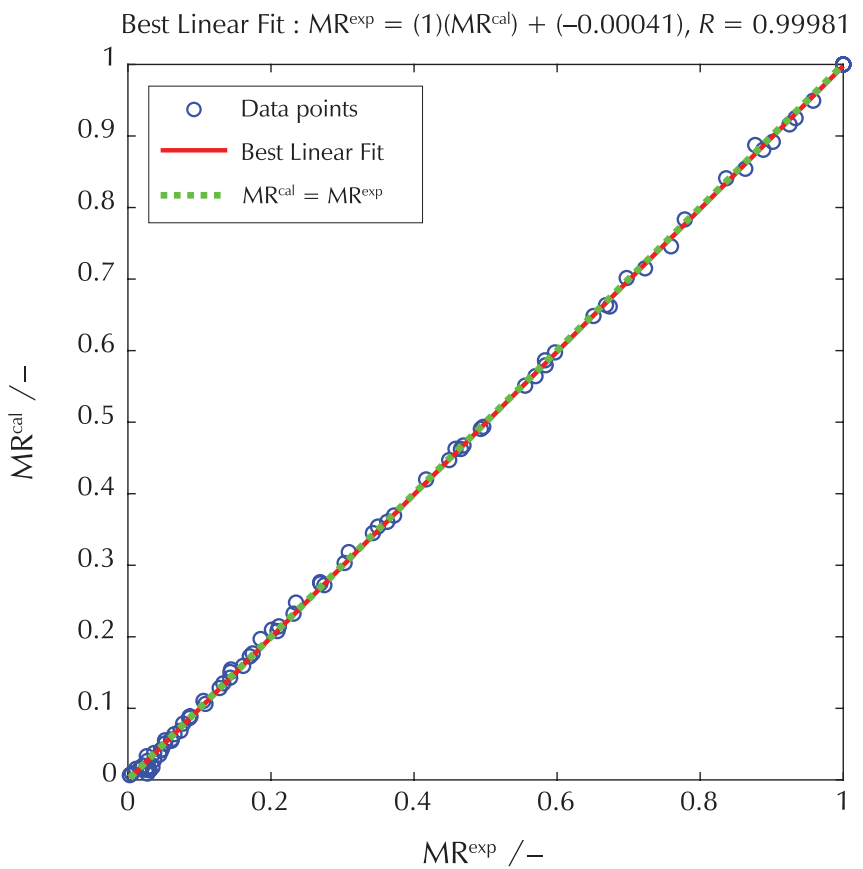

Fig. 7 - Linear regression between the experimental and the calculated moisture ratio using the proposed model (MR57) at different thicknesses (Ep) of the 15 selected kinetics

From Fig. 8, the proposed empirical model MR64 shows to be the best in terms of MRMSE and $R^{2}$; followed by the fractional model and the MR57 model.

\section{Conclusion}

The aim of this work was to model the phenomenon of apple drying in a thin layer using empirical and fractional methods. For this purpose, a dataset of 15 kinetics tak- en from previously published papers was extracted from drying kinetics of apple using Digitizer software. Sixty-four semi-empirical models were tested firstly, and based on the structure and performance of the best model, a semi-empirical model was proposed and tested using the same dataset. In addition, a novel model has been proposed using fraction calculus based on Fick's first law of $n$ order.

The proposed semi-empirical model proves to be the most efficient by modelling the fifteen kinetics with MRMSE of $0.43 \%, R^{2}$ of 0.9998 , followed by the fractional mod- 

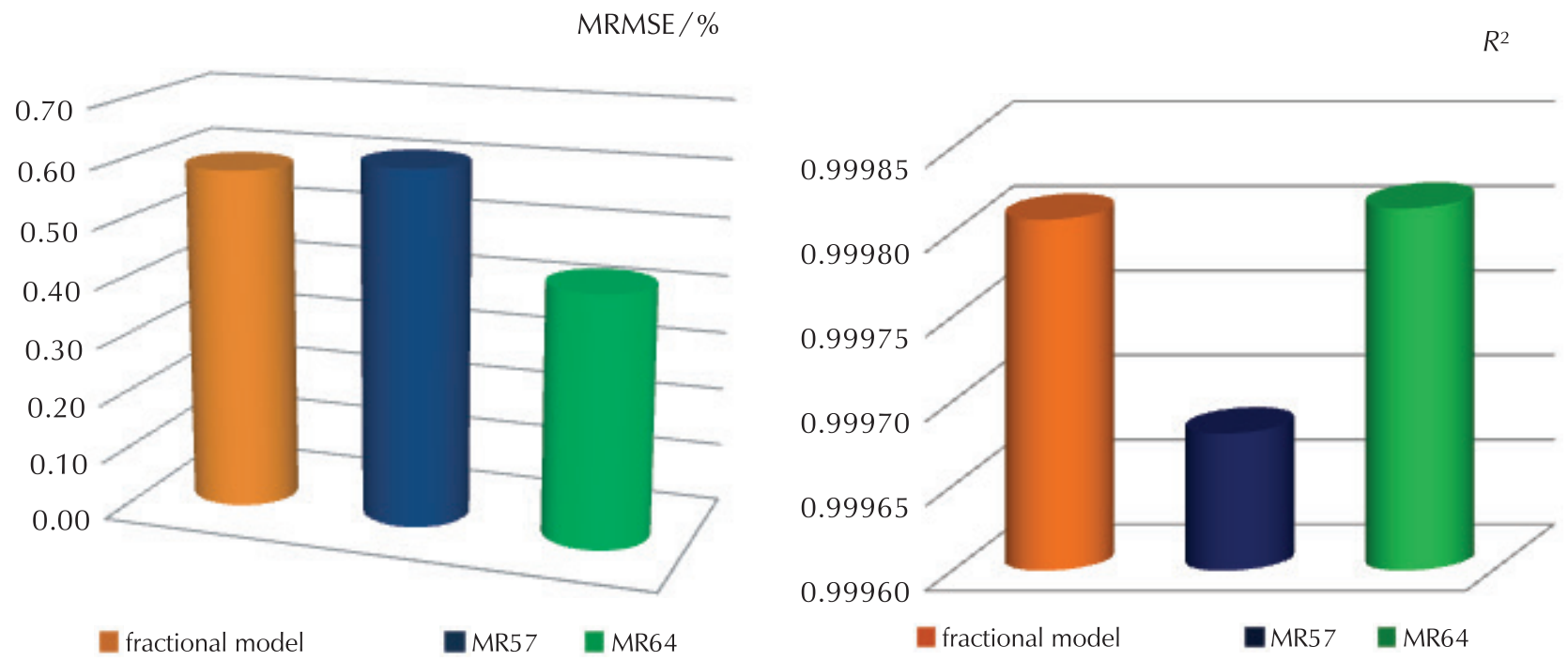

Fig. 8 - Comparison in terms of MRMSE (\%) and $R^{2}$ between the fractional model and the two semi-empirical models MR57 and MR64 by modelling the 15 kinetics of solar drying thin layers of apple

el with MRMSE of $0.59 \%, R^{2}$ of 0.9998 , and finally, the best model from literature (Regression I) with MRMSE of $0.61 \%, R^{2}$ of 0.9997 . The results show that the two proposed models can fit with accuracy the drying desorption kinetics during thin-layer apple drying in comparison with those models from literature.

\section{ACKNOWLEDGEMENTS}

This work is supported by Biomaterials and Transport Phenomena Laboratory (LBMPT), University of Médéa, Médéa City, Algeria. The authors also thank the anonymous reviewers for their constructive comments which helped to improve the quality and presentation of this paper.

\section{References \\ Literatura}

1. A. P. K. Joshi, H. P. V. Rupasinghe, S. Khanizadeh, Impact of drying processes on bioactive phenolics, vitamin $C$ and antioxidant capacity of red-fleshed apple slices, J. Food Process. Preserv. 35 (2011) 453-457, doi: https://doi.org//10.1111/ j.1745-4549.2010.00487.x.

2. D. Ježek, B. Tripalo, M. Brnčić, D. Karlović, S. Rimac Brnčić, D. Vikić-Topić, S. Karlović, Dehydration of celery by infrared drying, Croat. Chem. Acta 81 (2008) 325-331.

3. G. Adiletta, W. Senadeera, L. Liguori, A. Crescitelli, D. Albanese, $P$. Russo, The influence of abrasive pretreatment on hot air drying of grape, Food Nutr. Sci. 6 (2015) 355-364, doi: https://doi.org/10.4236/fns.2015.63036.

4. A. Djebli, S. Hanini, O. Badaoui, M. Boumahdi, A new approach to the thermodynamics study of drying tomatoes in mixed solar dryer, Sol. Energy 193 (2019) 164-174, doi: https://doi.org/10.1016/j.solener.2019.09.057.

5. Ó. Rodríguez, V. Eim, C. Rosselló, A. Femenia, J. A. Cárcel, S. Simal, Application of power ultrasound on the convective drying of fruits and vegetables: effects on quality, J. Sci. Food Agric. 98 (2018) 1660-1673, doi: https://doi.org/10.1002/ jsfa.8673.
6. A. Djebli, S. Hanini, O. Badaoui, B. Haddad, Modeling and comparative analysis of solar drying behavior of potatoes, Renew. Energy 145 (2020) 1494-1506, doi: https://doi. org/10.1016/j.renene.2019.07.083.

7. C. Ertekin, M. Z. Firat, A comprehensive review of thin-layer drying models used in agricultural products, Crit. Rev. Food. Sci. Nutr. 57 (2017) 701-717, doi: https://doi.org/10.1080/ 10408398.2014.910493.

8. S. Keskes, S. Hanini, M. Hentabli, M. Laidi, Artificial Intelligence and Mathematical Modelling of the Drying Kinetics of Pharmaceutical Powders, Kem. Ind. 69 (3-4) (2020) 137 152, doi: https://doi.org/10.15255/KUI.2019.038.

9. H. Maouz, L. Khaouane, S. Hanini, Y. Ammi, QSPR Studies of Carbonyl, Hydroxyl, Polyene Indices, and Viscosity Average Molecular Weight of Polymers under Photostabilization Using ANN and MLR Approaches, Kem. Ind. 69 (1-2) (2020) 1-16, doi: https://doi.org/10.15255/KUI.2019.022.

10. O. Yaldýz, C. Ertekýn, Thin layer solar drying of some vegetables, Dry. Technol. 3937 (2007), doi: https://doi. org/10.1081/DRT-100103936.

11. G. D. S. Matias, C. Andressa, B. Luiz, M. De Matos, The fractional calculus in studies on drying : A new kinetic semi-empirical model for drying, J. Food Process Eng. 42 (1) (2018) 1-7, doi: https://doi.org/10.1111/jfpe.12955.

12. M. K. Krokida, Rehydration kinetics of dehydrated products, J. Food Eng. 57 (2003) 1-7, doi: https://doi.org/https://doi. org/10.1016/S0260-8774(02)00214-5.

13. A. Yagcioglu, A. Degirmencioglu, F. Cagatay, Drying characteristic of laurel leaves under different conditions, in Proc. $7^{\text {th }}$ Int. Congr. Agric. Mech. Energy (Faculty of Agriculture, Cukurova University, Adana, Turkey, 1999), pp. 565-569.

14. B. Ameri, S. Hanini, M. Boumahdi, Influence of drying methods on the thermodynamic parameters, effective moisture diffusion and drying rate of wastewater sewage sludge, Renew. Energy 147 (2020) 1107-1119, doi: https://doi. org/10.1016/j.renene.2019.09.072.

15. S. Rafiee, E. Meisami-asl, Mathematical Modeling of Kinetics of Thin-layer Drying of Apple (var. Golab), Agricultural Engineering International: CIGR Journal o (2009), url: https://cigrjournal.org/index.php/Ejounral/article/download/1185/1228. 
16. S. Kaleemullah, R. Kailappan, Modelling of thin-layer drying kinetics of red chillies, Food Eng. 76 (4) (2006) 531-541, doi: https://doi.org/10.1016/j.jfoodeng.2005.05.049.

17. I. Doymaz, O. Smail, Drying characteristics of sweet cherry, Food Bioprod. Process. 89 (2011) 31-38, doi: https://doi. org/10.1016/j.fbp.2010.03.006.

18. W. Yang, Thin-layer drying kinetics of sesame hulls under forced convection and open sun drying, J. Food Process Eng. 30 (2006) 324-337, doi: https://doi.org/10.1111/j.17454530.2007.00119.x.

19. V. Antonio, E. Uribe, R. Lemus, M. Miranda, Hot-air drying characteristics of Aloe vera (Aloe barbadensis Miller) and influence of temperature on kinetic parameters, LWT 40 (2007) 1698-1707, doi: https://doi.org/10.1016/j. Iwt.2007.01.001.

20. N. Betoret, R. Lemus-Mondaca, A. Vega-Galvez, Charac- teristics of papaya (Carica pubescens): determination of equilibrium moisture content and diffusion coefficient, J. Food Process Eng. 32 (2007) 645-663, doi: https://doi. org/10.1111/j.1745-4530.2007.00236.x.

21. A. Benzaoui, A. Pina, P. Ferrão, J. Fournier, B. Lacarrière, O. Le Corre, Numerical investigation of absorber' s roughness effect on heat transfer in upward solar air heaters The investigation, Energy Procedia 157 (2019) 1089-1100, doi: https:// doi.org/10.1016/j.egypro.2018.11.276.

22. K. O. Falade, O. J. Solademi, Original article Modelling of air drying of fresh and blanched sweet potato slices, Food Sci. Technol. 45 (2) (2010) 278-288, doi: https://doi. org/10.1111/j.1365-2621.2009.02133.x

23. S. J. Babalis, E. Papanicolaou, N. Kyriakis, V. G. Belessiotis, Evaluation of thin-layer drying models for describing drying kinetics of figs (Ficus carica), J. Food Eng. 75 (2006) 205214, doi: https://doi.org/10.1016/j.jfoodeng.2005.04.008.

\section{SAŽETAK \\ Modeliranje kinetike sušenja jabuke (sorta Golab): Frakcijski račun u odnosu na poluempirijske modele \\ Abdelkader Mahdad, ${ }^{a}$ Mamar Laidi, ${ }^{a,}{ }^{*}$ Salah Hanini, ${ }^{a}$ Mohamed Hentablib i Mohamed Benhelala}

U ovom radu predložena su dva nova modela temeljena na poluempirijskom i frakcijskom računu koji uključuje necjelobrojne vremenske derivate u Fickovom prvom zakonu anomalne difuzije. Eksperimentalni podatci o 15 kinetika istraženih u konvektivnom sušioniku pod utjecajem temperatura u rasponu od 40 do $80{ }^{\circ} \mathrm{C}$ u razmaku od $10{ }^{\circ} \mathrm{C}$ i debljine kriški od 2 do $6 \mathrm{~mm}$ u razmaku od $2 \mathrm{~mm}$ prikupljeni su iz literature. Prikupljeni eksperimentalni skup podataka bio je na kriškama jabuke (sorta Golab). Rezultati ove studije uspoređivani su s nizom od 64 modela tankoslojnog sušenja koji su prethodno objavljeni u literaturi. Sposobnost uklapanja modela uspoređena je koristeći srednju vrijednost srednje kvadratne pogreške MRMSE (\%) svih kinetika i globalni koeficijent određivanja $R^{2}$. Konstante i koeficijenti svih modela optimizirani su algoritmom dragonfly programiranim u softveru MATLAB. Rezultati pokazuju da je frakcijski model visoko sposoban opisati krivulju sušenja kriški jabuke s koeficijentom utvrđivanja $\left(R^{2}\right)$ 0,99981 i prosječnom srednjom kvadratnom pogreškom (MRMSE) 0,43 \% u usporedbi s najboljim empirijskim modelima s $R^{2} 0,99968$ i MRMSE 0,61\%.

Ključne riječi

Tankoslojno solarno sušenje, frakcijski račun, poluempirijsko modeliranje, kriške jabuke

a Laboratory of Biomaterials and Transport Phenomena (LBMPT), University of Médéa, Médéa, Alžir

b Laboratory Quality Control, Physico-Chemical Department, Antibiotical Saidal of Médéa, Alžir
Izvorni znanstveni rad Prispjelo 28. srpnja 2020. Prihvaćeno 19. rujna 2020. 